\title{
Mana-ā-kī(tanga) and Tourism in Aotearoa
}

\begin{abstract}
The main focus of this article will discuss mana-ā-kì (tanga) and the tourism industry in Aotearoa (New Zealand). It will specifically investigate the interpretation of mana-ā-kī(tanga). Mana-ā-kîn(tanga) does not discriminate between people and it is a selfless and unconditional act, with no preconceived expectations. I learned that mana-ā-kī(tanga) could be shared, not only amongst whānau (family) but also with manuhiri (visitor), including those from overseas. It is no wonder therefore that the term mana-ā-kì (tanga) is embraced and promoted within Aotearoa, to manuhiri from foreign shores. The term mana-ā-kîn(tanga) is widely understood in the tourism industry as hospitality and reciprocity. Hence, possible misinterpretation of mana-ā-kī(tanga) could result in this concept being used incorrectly and lead to the transgression of cultural practices, thus compromising the experiences offered by Māori tourism operators. Throughout this article there is a deliberate emphasis on the spelling of mana-ā-kī(tanga) to show the importance of mana-ā-ki (respect earned from the recognition of others). Thus, the spelling in the English alphabet of manaakitanga and manaaki is used intermittently.
\end{abstract}

\section{Origins}

The origins of the word mana-ā-ki and mana-ā-ki(tanga) derive from the word mana. Mana-aki can be interpreted as mana which derives from a person's ability to care for manuhiri. Akiaki, upon further analysis of mana-aki, is described by Williams (1975) as urge on. Hence, within this context, encouraging the support of manuhiri is fundamental in understanding manaaki. The use of the suffix -tanga in manaakitanga changes a verb to a noun. As outlined by Moorfield (2005), -tanga is a suffix that is added to a noun to

Frances Kahui Martin is a PhD Student at Te Ara Poutama - AUT University's Faculty of Maori Development. 
designate the quality obtained from the base noun. According to Pere (1982) mana encompasses numerous meanings such as power, control and influence. Nevertheless, Pere (1991, p32) does caution that the concept of mana is "beyond translation from the Māori language". From the term mana, derives respect that is earned and cannot be forced upon any individual. The notion of mana-ā-kī, therefore, can be considered mana given by statement after an experience (good/bad or otherwise). Moreoever, the mana of an individual can be affected through the ' $\bar{a}-k \bar{i}$ ' or declaration and recognition by others. For example if Wiremu creates a positive experience for Takirimu, this experience is then discussed with another group of people such as Takirimu's whānau. Thus, mana is bestowed upon Wiremu through ' $\overline{\mathrm{a}}-\mathrm{k} \overline{\mathrm{i}}$ ' by not only Takirimu but also her whānau.

In recent times, there has been an increased presence of the term manā-ā-kì (tanga) in tourism related documents, which has generated several interpretations of this cultural concept. It is essential therefore, that the role of tourism in Aotearoa is explored. This is followed by a discussion of Māori involvement in tourism. To begin with, though it is useful to discuss how the word mana-ā-kî̀(tanga) can be described as hospitality and originates from the word mana.

\section{Mana-ā-kīi(tanga)}

Mana-ā-kîn(tanga) plays an important role in Māori society. As a customary concept, mana-ā-kîltanga) is regarded as an expected standard of behaviour (Mead, 2003). However, it is loosely translated as hospitality in the tourism industry (Ryan, 1997; Zygadlo, McIntosh, Matunga, Fairweather \& Simmons, 2003; Tourism New Zealand, 2007). An increased presence of this term in tourism literature from both government public servants and academics has resulted in the appearance of a number of interpretations of the term mana-ā-kì (tanga). It is important therefore, that a contextual understanding of mana$\bar{a}-k i(\operatorname{tanga})$ is sought within the wider frame of Māori culture and Māori cultural concepts. 
Mana or inherent powers are referred to by Best (1925) in his descriptions of Māori folk-lore as being possessed by an individual which can then be used against another individual. This view is supported in the Ministry of Justice document 'He Hinatore ki te Ao Māori- A glimpse into the Māori world' (Ministry of Justice, 2001) where mana is recognised as a spiritual power that can be possessed by an individual or group. Furthermore, in the Māori-Polynesian comparative dictionary, Tregear, (1891) defines mana as power and supernatural power in the Samoan, Tahitian, Hawaiian, Tongan and Rarotongan languages showing a commonality of the word throughout Polynesia. Therefore, the word manaaki derives from the word mana means to convey hospitality and love to people (Barlow, 1991). Barlow (1991) explains in Māori culture, the mauri manaaki or talisman of hospitality is placed on the left handside of an ancestral building. Therefore, the responsibility of the host is to ensure that the mana of the manuhiri (visitor) is upheld. Maintaining this hospitality is imperative in Māori society and there are many examples of this ' $\mathrm{a}-\mathrm{k} \hat{\imath}$ ' in pēpeha (proverbs). For example, 'makue ana te reka o te kai', literally translated means 'the aroma of the food is very pleasant'. This pēpeha makes reference to the fragrant smell of the food, makue meaning pleasing to taste (Mead \& Grove, 2001, p279). The courteous comment at a hākari (feast) is a compliment for the hosts.

Another example is, 'ko Maru kai atu, ko Maru kai mai, ka ngohengohe', literally translated means 'Maru who ate abroad, and at home, was agreeable' (Brougham, Reed \& Karetu, p72, 1987). This expression refers to Maru, who was known to generously provide food and was pleasant and kind hearted. Yet another example, 'te kai ngaro, he putanga whananga ka kitea', literally translated this means 'that concealed food is found when a party of travellers appear' (Mead, 2001, p372). A practical woman gave this response when asked why she put food away from regular use. In other words it is a sign of prudent planning of food being kept aside for visitors.

Other proverbs are cautionary reminders $(\overline{\mathrm{a}}-\mathrm{k} \overline{\mathrm{i}})$ of the ramifications of not providing mana- $\overline{\mathrm{a}}-\mathrm{k} \overline{\mathrm{l}}$ (tanga). An example of this is 'Kai ana mai koe he atua; noho atu ana ahau he 
tangata'. This pēpeha states that 'you are eating like a god; I am sitting here as a man' (Brougham et al, 1987, p72). It is advice against inhospitality. The lesson learnt is that if a visitor arrives they should be asked to share a meal. If the unknown person is thought to be of low birth, they may invariably be a tohunga (priest) with power to cause death from such an offence.

Brougham et al (1987) contend that in Māori society, proverbs demonstrate a person's oratory skills. The person's ability is exemplified not only from their recollection of these sayings $(\overline{\mathrm{a}}-\mathrm{k} \overline{\mathrm{i}})$ but also the application which is appropriate to the occasion. These guidelines of appropriate behaviour in Māori society are referred to as tikanga. Tikanga, as described by Williams (1975) can mean rule, plan, method, custom, reason, correct and authority.

While these concepts may be common amongst some tribes, the way in which they are applied may vary from tribe to tribe or between families (Pere, 1982). Notably, mana-ākì (tanga) was not necessarily performed between two friendly parties (Ryan, 1997). Nevertheless, mana-ā-kī(tanga) pervades the philosophy of Māori life in sharing and caring for other people. The significance of mana-ā-kì(tanga), as affirmed by Mead (2003), is that it is applicable to all social gatherings ( $\bar{a}-$ kī) when manuhiri are hosted by tangata whenua (the indigenous people of the land).

These multi-layered understandings of mana-ā-kì (tanga) reveal that this customary concept is more than just 'hospitality' as maintained within the tourism industry. Mana$\bar{a}-k \overline{1}$ (tanga) is a cultural value that does not involve the exchange of money. It is important then, to explore how mana$\bar{a}-k \bar{i}($ tanga) is understood in the tourism industry.

\section{Ngā ahumahi tāpoi ki Aotearoa - Tourism in Aotearoa}

In Aotearoa, tourism (ā-kī) plays a substantial role in the economy with the creation of employment opportunities and the production of services and products. Tourism, as noted by Collier (2006), is Aotearoa's primary export industry. On an economic scale, tourism is a powerful force internationally and 
the influence on New Zealand is no exception (Collier, 2006). From 2004 to 2007, direct tourism employment increased by 5.2 percent with 108,100 full time equivalent persons directly involved in tourism in the year ended March 2007 (Statistics New Zealand, 2008). In addition, direct tourism contribution was 5.1 percent or $\$ 7.9$ billion of gross domestic product (GDP) (Statistics New Zealand, 2008). Thus, the increasing emphasis on tourism, particularly cultural, has resulted in a rising dependence on Māori knowledge as a point of reference in a competitive global arena (Collier, 2006; Rod, Todd, Krisjanous, Love, Gutherie \& Spanier, 2005). For the New Zealand Ministry of Tourism (2004, p21), Māori culture "provides a key distinctive element" for attracting international visitors.

In recent times, there has been an increased presence of the term mana-ā-kì (tanga) in tourism related documents, which has generated several interpretations of this cultural concept. Currently, various government organisations use this concept as a basis for developing both short and long-term strategies. This is particularly noticeable in the New Zealand Tourism Strategy 2015. However, there are varied interpretations of the term mana-ā-kì (tanga) by the tourism industry, which are in conflict with Māori operators understanding and knowledge of mana- $\bar{a}-k \bar{i}$ (tanga) reflected in their businesses.

While there is a demand from manuhiri for more 'experiential' encounters with the host, the authenticity of this interaction is widely debated in the tourism industry. It has been argued that manuhiri seek authenticity as opposed to the contrived touristic situation. Notions of imperialism and colonialism have become apparent in tourism through the reference of indigenous people like Māori as the 'other'.

In 2005, Tourism New Zealand classified the ideal visitor to Aotearoa as the 'interactive traveller'. The 'interactive traveller' seeks new encounters that encompass interaction with natural, cultural and social environments (Tourism New Zealand, 2005). In addition, this 'interactive traveller' through experience can recommend ' $\bar{a}-\mathrm{k} \bar{\imath}$ ', the benefits of visiting Aotearoa to family and friends (kia taea ai te kî: to be able to 
say). With similar attributes to what Mowforth and Munt (2003) outline as the 'new petit bourgeois', the 'interactive traveller' seeks culturally enriching experiences. These types of Māori cultural experiences add value to the overall visitor experience (Wilson, Horn, Sampson, Doherty, Becken \& Hart, 2006). With this in mind, it has become increasingly evident in tourism, that Māori values are being incorporated into marketing campaigns, government documents policies and organisational charters. Tourism New Zealand (2007, p78) defined mana-ā-kì (tanga) as "sharing exceptional and natural hospitality, knowledge and beliefs, on the basis of mutual respect between the host and visitor". In addition, the New Zealand Government incorporated the cultural value mana-ākîltanga) and kaitiakitanga (guardianship) throughout the Tourism New Zealand Strategy 2015 (2007). The strategies outlined in this document are intended for the tourism industry of Aotearoa.

As reported by Ryan and Pike (2003) mana-ā-kì (tanga) encapsulates the spirit of hospitality and thus Tourism Rotorua has used the catch phrase "Feel the spirit Manaakitanga" as part of their marketing brand. This local government organisation is situated in Rotorua, the "so called Māori capital of New Zealand" (Taylor, 2001, p16). The value of a brand as suggested by Kotler and Armstrong (2003) derives from the visitor's perception of products and services. It is an integral component within tourism as it differentiates products and services, also adding a 'perceived value' for the sensible visitor (Holloway, 2004) thus, 'ā-kì' derived from tangible evidence. This marketing approach undertaken by Tourism Rotorua reinforces customer perception through the high visibility of signs and logos throughout the city of Rotorua, aimed at both domestic and international visitors. These signs can act as indicators to the logical consumer, identifying the quality expected from the brand (Kotler \& Armstrong, 2003). Although Tourism Rotorua has employed the phrase 'Feel the spirit - Manaakitanga', the word mana-ākì (tanga) is dissimilar to the expression 'feel the spirit'. Mead (2003) acknowledges that mana-ā-kî̀(tanga) is a term frequently linked with food and accommodation and has 
extensive implications. Moreover, the Māori sensory perceptions are of two worlds, the unseen and the seen in fluid motion.

The term 'spirit' according to the Oxford thesaurus, can be informally referred to as a demon, devil, ghost or genie (Spooner, 1992). As noted by Moon (1993, p116), "translation between languages usually necessitates the reconciliation of different modes of thinking as a priority over terminology". Obviously, the statement 'feel the spirit' and 'mana-ā-kì (tanga)' are two different concepts with diverse meanings, yet they are combined and marketed to the visitor. Mana-ā-kì (tanga) is by definition is received not forced therein lies the contradiction forced by the unenlightened.

Ryan (1997) expresses concern about placing the label 'authentic' on Māori tourism products for visitor consumption. This notion is reiterated by Sharpley and Telfer (2002) that propose in a competition driven market, tourism producers are challenged to offer cultural traditions of a destination as demanded by visitors. For tourism organisations that employ Māori concepts, it is necessary to consider the cultural context in which these concepts belong. This can be achieved through enhancing manuhiri knowledge and appreciation of Māori encounters (Ryan, 1997).

Essentially, Māori culture has become a valuable commodity in tourism marketing to attract the international visitor. Commodification, as argued by Cohen (1988), changes the significance of cultural products and human connections ultimately making them meaningless. Conversely, it can be argued that these cultural products are not meaningless to the producer, but to the consumer. These images marketed to the global visitor have often featured Māori people in traditional costume. For government organisations, the inclusion of cultural values supposedly affirms a collaborative effort with the tangata whenua. Since the 1870s, Māori people have featured in tourism brochures to attract visitors from international shores (Hinch \& Butler, 1996). Māori culture, with regard to tourism marketing terminology, would be used as a poit of difference rather than a serious attempt to include Māori. Hence, Māori culture and in particular, the terminology 
used is being interpreted by the New Zealand government and redistributed to the tourism industry as a tourism strategy. In doing so, the government through tourism undermines the very cultural system to which cultural values such as mana-ākì (tanga), belong.

\section{Te urunga a te Māori ki ngā ahumahi tāpoi - Māori involvement in tourism}

Some of the earliest accounts of Māori controlled tourism in Aotearoa emerged more than 120 years ago, when Māori began to guide manuhiri to the Pink and White Terraces, Lake Rotomahana, Rotorua (Dennan \& Annabell, 1968). Before a journey to the Pink and White Terraces, manuhiri would gather at Te Wairoa, located approximately twenty kilometres from Rotorua. In the village of Te Wairoa, the local Māori community were able to control access to the terraces benefited from manuhiri desire to view the natural environmental through the commodification of landscape (Bremner, 2004). Prior to the destruction of the terraces, a waka taua sighted by both manuhiri and tangata whenua, and understood to have been a warning of an eminent event. This destruction of the terraces in 1886, due to the eruption of $\mathrm{Mt}$ Tarawera, resulted in the dispossession of land holdings. The unseen world spoke and the seen world chose what to hear, hence we choose how and what 'spirit we wish to feel'. Consequently, some survivors relocated to gifted land from Ngāti Wahiao at Whakarewaerewa, Rotorua (Bremner, 2004). Limited tourism opportunities for Māori were developed in the town of Rotorua and in particular guided tours through the geothermal area of Whakarewarewa (Dennan \& Annabell, 1968).

Over the past 200 years, Benton (1991) found that, many social and economic changes experienced by Māori have been negative rather than positive, resulting in underdevelopment as opposed to development. Pākehā (people of European descent) control of tourism in New Zealand, as maintained by Hall (1996) created animosity with Māori, especially as there was low economic return from tourism. From the late 1800s 
until the mid 1900s, very little material has been written about Māori participation in tourism (Barnett, 2001), probably due to the fact that they were excluded from the government tourism department apart from isolated and government sponsored products. Additionally, during this time Māori were being colonised. In 1881, parliament passed the Thermal-Springs Districts Act which allowed the government to reserve thermal areas for the public (McClure, 2004). This Act gave the government the ability to determine areas of interest that could be designated as a thermal spring's district. In doing so, Māori who owned land in these areas could only sell to the government, thus preventing the progress of Māori participation in tourism, as they would not receive market value for their land to assist with start up costs for a tourism business.

Barnett (2001) identified that Māori involvement was restricted to images used by tourism marketing boards for promotional material. More specifically, images produced in the 1900s by the Department of Tourist and Health Resorts showed Māori carvings and Māori maidens wearing traditional costume (Ateljevic \& Doorne, 2002). As highlighted by Carr (2004) these media stereotypes emphasised Maōri as the foreign 'other', further differentiating Māori from the international visitor. These visual representations of Māori people gave manuhiri a preconceived idea of the types of images to be encountered and had the propensity to be profit driven. Silver (1993) maintains that these marketed depictions of culture can be one-dimensional effectively creating stereotypes of indigenous people. As described by Ateljevic and Doorne (2002, p656) Māori were "exploited for their exotic allure" in these types of images. Similiarly, the use of Māori words, such as 'manaakitanga' by government, (Tourism New Zealand, 2007) are used as an 'exotic allure', enticing the international manuhiri and further promoting Aotearoa as a tourism destination. Ryan and Pike (2003), reiterate this notion when they suggest there is little effort to challenge this stereotype of Māori tourism representation. In the report 'Demand for Māori eco-cultural tourism', tourism marketing of Māori culture by the New Zealand government is identified as 
minimal (Wilson et al, 2006). The development of the ' $100 \%$ Pure New Zealand' campaign allowed the crown entity, Tourism New Zealand, to focus marketing efforts on the open wide spaces of Aotearoa rather than Māori culture. Moreover, the internet website, www.purenz.com, permits manuhiri to download and send e-cards of varied Aotearoa landscape. At a regional level, government tourism-related organisations highlight the attractions of their areas such as Napier's art deco features and Marlborough's fine wines. Apart from the city of Rotorua, it is evident that there is less emphasis placed on the promotion of Māori culture to both a domestic and international audience. Thus, one could assume Māori culture was of limited importance based on these marketing attempts.

In 1983 the New Zealand government took control of the Māori Arts and Crafts Institute (now known as Te Puia) located in one of New Zealand's most popular tourism destinations, Rotorua. By the $21^{\text {st }}$ century, Te Puia became one of the most visited attractions in Rotorua when measured by visitor numbers (Ryan \& Pike, 2003). This cultural centre includes Māori cultural performances, Māori arts and crafts, thermal valley, kiwi house and a model pā (traditional Māori fortified village). The board of governance for Te Puia comprises of up to seven elected members determined by the Governor General on the advice of the Minister of Tourism. During (1998) argues that in this environment, based on their terms, Māori to some extent achieve and have access to a global audience. This suggestion fails to recognise the type of environment that has been established for manuhiri consumption. For example, performers in Māori concert parties had to align themselves with the visitor's image of a seductive woman from the Pacific. Woman who were 'too fat' or 'too black' were replaced with slendour, glamorous and paler performers for the front row of Māori cultural performance parties (McClure, 2004). Furthermore, the marae (the open area in front of the meeting house) built on these premises primarily caters to the inquisitive manuhiri who has paid their entry fee at the gate, as opposed to being a communal place of gathering for Māori. While the government may consult regularly with the local iwi (tribe), ownership still remains firmly with the government. It 
can be argued therefore, that Māori are marginalised as entertainment for visitor consumption (Ryan, 1997) rather than having the ability to own and operate a successful tourism venture.

As a founding document of Aotearoa the Treaty of Waitangi signed in 1840, represents the fundamental principles of partnership between Māori and Pākehā and presumes a relationship that is mutually beneficial. Leading up to the signing on February the $6^{\text {th }} 1840$, over five hundred chiefs signed the Treaty with the British Crown in Waitangi, Bay of Islands (Orange, 1987). This founding document takes its name from Waitangi and is now recognised as a public holiday in Aotearoa called Waitangi Day. As chief negotiator for the Crown, William Hobson assumed sovereignty of northern Aotearoa, based on the agreement with a select group of Māori rather than a majority of Māori (Orange, 1987). This matter remains highly contentious and has implications for tourism, as Māori involvement can no longer be pushed to the periphery. Only recently, alongside the resurgence of Māoritanga (distinctive Māori cultural behaviour) in the 1970s and the Māori Renaissance in the 1980s, have Māori tourism operations become more prominent. These opportunities of employment for Māori have led to the formation of partnerships and a growth of ownership in various tourism related business.

During the 1990s there was a significant increase in Māori investment and involvement in tourism (Pearce, 2001). Walker (1996) highlights the movement by some tribes to protect the cultural and intellectual property rights of tangata whenua. Following Treaty of Waitangi negotiations, tribes such as Ngāi Tahu and Tainui have made substantial financial contributions to various tourism ventures in Aotearoa. For instance, a number of businesses owned or invested in by Ngāi Tahu include the Shotover Jet, Rainbow Springs, Huka Jet, Christchurch Tram and Whale Watch Kaikoura (Stafford Group, 2001). Māori visibility in a commercial arena has increased and in tourism this has resulted in a greater control of resources with the development of new businesses. Throughout Aotearoa, there are approximately 350 Māori 
tourism businesses that are registered members of the New Zealand Māori Tourism Council (NZMTC) (Ministry of Tourism, 2008). Of these businesses, some offer a tourism product with a Māori cultural component, while others provide more 'monostream' and 'homogenised' tourism product or service.

Māori cultural tourism according to the Ministry of Tourism $(2004, \mathrm{p} 8)$ is described as "tourism experiences that include visits to Māori cultural activities (demand perspective)". Following on from this is the term, Māori in tourism, which is described by the Ministry of Tourism (2004, p8) as "Māori involved in the tourism industry through employment or ownership of businesses that deal with tourism products supply perspective".

Wilson et al (2006) further explains that the term 'Māori in tourism', does not necessarily exemplify a cultural component. This is considerably different to the phrase, 'Maori tourism' which is also referred to as a 'Māori tourism business' and 'Māori tourism product'. One definition of Māori tourism as proposed by Barnett (2001) is that the operation must offer a Māori tourism product and Māori ownership must be more than fifty percent. Ingram $(1997, \mathrm{p} 2)$ draws upon the same criteria adding that Māori tourism encompasses tourism products utilising "cultural, historical, heritage or natural resources" important for Māori with considerable Māori control and possession of the business.

While these definitions highlight that Māori participation in tourism has expanded, mana-ā-kī, Māori culture is still being interpreted in the tourism industry by entities such as the government. The government may consult with some Māori groups about the use of Māori culture in tourism rather than attaining general agreement from the wider Māori community. On reflection, the Treaty of Waitangi gave the British sovereignty the opportunity to settle Aotearoa, secured through an agreement with a select group of Māori. Thus, greater control over decision-making and planning regarding Māori culture in tourism needs to be articulated by Māori for Māori rather than for Māori by non-Māori. Māori control draws on tino rangatiratanga (self determination) and in a tourism context, the interpretation of Māori culture belongs to the 
Māori community. As noted by Carr (2004) the course of ascertaining information for public consumption is a persistent concern for Māori. Hence, it is important that operators involved in Māori tourism ventures provide their own interpretation of mana-ā-kî̀(tanga), rather than accepting a definition imposed by government.

\section{Conclusion}

These multi-layered understandings of mana-ā-kì (tanga) reveal that this concept is more than just 'hospitality' as maintained within the tourism industry. Mana- $\overline{\mathrm{a}}-\mathrm{k} \mathbf{1}$ (tanga) is a cultural value that does not necessarily involve the exchange of money. However, it can be regarded as an imperative that encompasses the sharing and caring of relationships between a host and manuhiri. The well-being of the manuhiri is paramount to the development of this relationship as the mana-ā-ki of the host is defined by the manuhiri.

The impact of tourism, while financially beneficial to a select few, has the propensity to be exploitative, as dominant cultures continue to impose their monoglot systems thereby disenfranchising the indigenous owners. These issues of power and control in tourism are encountered by indigenous people globally including Māori. These challenges however, have not discouraged Māori involvement in tourism particularly with the development of numerous Māori tourism businesses.

Over the past two to three decades, Māori have developed their expertise, as indigenous owners, and as a result there has been a steady growth of Māori tourism businesses that incorporate Māori cultural values. Mana-ā-kī(tanga), as a key Māori cultural value that formed the basis of traditional Māori society, and in contemporary times, is also a lived value that is practised within Māori tourism businesses. It is also recognised as a value that is commonly encountered amongst whānau.

The author suggests that the tourism industry should be flexible enough to adapt to the needs of Māori within the tourism industry, as Māori owners can provide the cultural capital that manuhiri can feel within culturally specific 
environments. Furthermore, there is a strongly actioned belief that Māori have the capacity to shape their own destiny in life that is reflective of philosophies such as mana motuhake (absolute power), rangatiratanga (self-determination) and 'by Māori, for Māori'.

Māori culture has moved away from activities such as hāngi and Māori cultural concerts in hotels due to the development of new products and services designed with the idea of exposing the manuhiri to a Māori world-view. While these types of activities appeal to mass tourism, this superficial view of Māori does not exemplify who Māori are as a people which was the catalyst for these new developments. Māori involvement in businesses have historically incurred years of suppression and subordination resulting in Māori having the belief that they were incapable of managing their own affairs. Nevertheless, it can be lonely for a business particularly for Māori who are attempting to establish themselves amongst other non-Māori operators.

For Māori tourism operators, being competitive requires an ability to sell and market themselves and their tourism business. A key marketing strategy is simply 'being themselves'. This acceptance that Māori can be themselves alleviates any romanticised representation of Māori culture and allows the visitor access to a genuine, authentic cultural experience. More importantly, these Māori tourism operators are now controlling the way in which Māori culture is interpreted. This is achieved through close consultation with kaumātua (elders), whānau, hapū (kinship group) and iwi (extended kinship group).

With a growth in Māori participation in tourism, there is recognition within te ao Māori (a Māori world-view), that Māori indeed want to share their cultural environment, their narratives and their lives which are informed by their worldview. For Māori tourism businesses to maximise their opportunities to grow, they must strategically position themselves in a competitive tourism industry.

Dissatisfaction by Māori with the imaging and representation of Māori in the past as the exotic for visitor consumption has seen a rise in Māori tourism operations 
seeking to portray Māori culture more accurately. The provision of the exotic for visitor consumption is a complex notion for the monoglot tourism sector particularly as mana-ākì (tanga) cannot be consumed There is concern that power and control in a 'market driven' tourism environment of Māori culture still remains at the disposable of non-Māori. Moreover, Māori are striving to become more vigilant in controlling and interpreting their own culture and showing the 'real' Māori. This is especially noticeable in whānau-based businesses where there is an emphasis on the business reflecting a Māori outlook. Some Māori tourism operators are able to offer 'real' experiences by engaging with their manuhiri in conversation, by sharing a meal and more significantly allowing their manuhiri to feel like a part of their family. It has been this family atmosphere that manuhiri most appreciate with the occasional tear shed on departure. Furthermore, these experiences allow manuhiri to 'feel the spirit'. Whānau members work collectively rather than individually as the Māori world-view is all about collective effort for collective gain. Therefore, interpretation of Māori culture encompasses a whānau ownership.

There is a reality, that for too long non-Māori have been incorrectly telling Māori stories and Māori histories through their own cultural lens primarily for financial profit. In contrast, these same stories of cultural significance to Māori are now being portrayed by Māori accurately without embellishment to suit a consumer palate.

Cultural values such as mana-ā-kì (tanga) and whanaungatanga (kinship) provide the manuhiri with real experiences. Through living, feeling and experiencing tikanga within an activity, manuhiri are offered a perceived glimpse into Māori culture and a Māori world-view. While there are a range of activities which offer varying degrees of Māori culture, it is these types of experiences that manuhiri have the opportunity to 'feel the spirit'.

The role of whannau is important for the survival of some Māori tourism businesses. For many Māori tourism operators there are positive and rewarding results to work as a collective as opposed to only a few being rewarded. These benefits 
include employment opportunities not only amongst the whānau but also for hapū and iwi. As a collective these Māori tourism operators are able to form strong networks.

Māori are now determining how Māori culture will be shared with their manuhiri. Providing a basic understanding of tikanga Māori broadens the experience of manuhiri engaging in a product or service offered by a Māori tourism operation.

Traversing between two cultures is a reality for these Māori tourism operators. Not only do they have responsibilities within their own business, but they are also responsible to their whānau, hapū and iwi. As Māori culture provides a point of difference in the tourism industry there is a drive to including cultural values into tourism businesses across the board. However, it is Māori tourism bussinesses which have the upper hand now because they are able to deliver a perceived 'real' experience from the basis of being Māori. Furthermore, they are able to show mana-ā-kì (tanga), because they are driven by cultural values such as mana-ā-kì (tanga) and not simply financial gain. Therefore, tourism activities that are solely driven to generate money will struggle in the new order of tourism where the manuhiri is seeking the authentic Māori experience. Māori tourism operations deservedly, will continue to flourish.

'He tangata takahi manuhiri, he marae puehu.'

'If one tramples or fails to respect visitors, the marae becomes dusty.'

This axiom of Māori hospitality underlines the paramount importance of (courtesy to) visitors (Mead \& Grove, 2001:121). Mana-ā-kì (tanga) is lived and practiced, and an integral part of my whānau upbringing. Thus, mana-ā-kī(tanga) is experienced through observation, practice and experience. 


\section{Glossary of Mãori Terms in the Context of this Article}

Most meanings of the terms in this glossary have been sourced from Moorfield, J. C. (2005). Te Aka; Māori-English, English-Māori Dictionary and Index and the online equivalent, which can be found at www.maoridictionary.com

$\overline{\mathrm{a}}-\mathrm{k} \overline{1}$

Aotearoa

used to refer to New Zealand

hākari

hapū

section of a large tribe

iwi

tribe

kaitiakitanga

kaumātua

kia tae ate $\mathrm{k} \overline{\mathbf{1}}$

mana

manaaki

hospitality

mana-ā-kī(tanga)

hospitality, sharing and caring

mana motuhake

manuhiri

Māori

marae

front of the wharenui

mauri manaaki

pā

Pākehā

pēpeha

rangatiratanga

tangata whenua

land

te ao Māori

tikanga

customary lore

tino rangatiratanga

tohunga

whānau to say

North Island, commonly

sumptuouos meal, feast

kinship group, sub-tribe,

extended kinship group,

guardianship

to grow old, elders

to be able to say

prestige, power

to support, take care of,

kindness, to show

absolute power

visitor or visitor

Aboriginal inhabitant

courtyard- the open area in

talisman of hospitality

Māori fortified village

people of European descent

proverbs

self-determination

indigenous people of the

a Māori worldview

correct procedure, custom,

self determination

priest

extended family 


\section{Bibliography}

Amoamo, M. (2007). Māori tourism: Image and identity - a postcolonial perspective. Annals of Leisure research, 9(3-4), 454474.

Ateljevic, I., \& Doorne, S. (2002). Representing New Zealand tourism imagery and ideology. Annals of Tourism Research, 29(3), 648-667.

Barlow, C. (1991). Tikanga whakaaro: Key concepts in Māori culture. Auckland: Oxford University Press.

Barnett, S. (2001). Manaakitanga: Maori hospitality-a case study of Maori accommodation providers. Tourism Management, 22(1), 8392.

Benton, R. A. (1991). Maori English: A New Zealand Myth. In J. Cheshire (Ed.), English around the world: Sociolinguistic perspectives (pp. 187-199). Cambridge: Cambridge University Press.

Best, E. (1925). Tuhoe: The children of the mist. Wellington: A.H. \& A.W. Reed.

Bremner, H. (2004). Constructing, contesting and consuming New Zealand's tourism landscape: A history of Te Wairoa. Unpublished Doctoral thesis, Auckland University of Technology, Auckland.

Brougham, A. E., Reed, A. W., \& Karetu, T. S. (1987). Maori proverbs. Auckland, N.Z: Reed Methuen.

Carr, A. (2004). Mountain places, cultural spaces: The interpretation of culturally significant landscapes. Journal of Sustainable Tourism, 12(5), 432-459.

Cohen, E. (1988). Authenticity and commoditization in tourism. Annals of Tourism Research, 15(2), 371-386.

Collier, A. (2006). Principles of tourism (7th ed.). Auckland: Pearson Hospitality Press.

Dennan, R. R., \& Annabell, J. R. (1968). Guide Rangi of Rotorua. Christchurch: Whitcombe \& Tombs.

During, S. (1998). Postcolonialism and globalisation: A dialectical relation after all? Postcolonial Studies: Culture, Politics, Economy, $1(1), 31-47$.

Hall, C.M. (1996). Tourism and the Maori of Aotearoa, New Zealand. In R. Butler, \& T. Hinch (Eds.), Tourism and Indigenous peoples. London: Thomson Business Press.

Hinch, T., \& Butler, R. W. (1996). Tourism and Indigenous peoples. London: International Thomson Press.

Holloway, J. C. (2004). Marketing for tourism (4th ed.). London: Prentice Hall.

Ingram, T. (1997). Tāpoi tangata whenua: Tāpoi Māori ki Aotearoa (Indigenous tourism: Māori tourism in Aotearoa). Proceedings of Trails, Tourism and Regional Development Conference, Centre for Tourism, University of Otago, New Zealand.

Kotler, P., \& Armstrong, G. (2003). Principles of marketing (10th ed.). London: Prentice Hall. 
McClure, M.(2004). The wonder country:Making NewZealand tourism. Auckland, New Zealand: Auckland University Press.

Mead, M. H. (2003). Tikanga Māori: Living by Māori values. Wellington: Huia Publishers.

Mead, H. M., \& Grove, N. (2001). Nga pēpeha a nga Tipuna. Wellington: Victoria University Press.

Ministry of Justice. (2001). He hinātore ki te ao Māori: A glimpse into the Mãori world: Māori perspectives on justice. Retrieved April 18, 2007,

from http://www.justice.govt.nz/pubs/reports/2001/Maori_perspectiv es/index.html

Ministry of Tourism, NZ. (2004). Measurement of Māori in tourism: Te ahu mai- he tatau tāpoi Māori. Retrieved February 19, 2007, from http://www.tourismresearch.govt.nz/Data--Analysis/Researchprojects-reports-and-studies / Research-Reports/Maori-inTourism/

Moon, P. (1993). Maori social and economic history to the end of the Nineteenth Century. Auckland, New Zealand: Huia Publishing.

Moorfield, J. C. (2005). Te Aka: Māori-English, English-Māori dictionary and index. Auckland, New Zealand: Pearson Education.

Mowforth, M., \& Munt, I. (2003). Tourism and sustainability. New York: Routledge New York.

Orange, C. (1987). The Treaty of Waitangi. Wellington: Bridget Williams Books.

Pearce, D. (2001). Tourism. Asia Pacific Viewpoint, 42(1), 75-84.

Pere, R.R. (1982). Ako: Concepts and learning in the Māori tradition (Working Paper No, 17). Hamilton: Department of Sociology, University of Waikato.

Rod, M., Todd, S., Krisjanous, J., Love, M., Guthrie, J., Spanier, N., et al. (2005). The New Zealand marketing environment. Auckland: McGraw-Hill.

Ryan, C. (1997). Maori and tourism: A relationship of history, constitutions and rites. Journal of Sustainable Tourism, 5(4), 257.

Ryan, C., \& Pike, S. (2003). Maori-based tourism in Rotorua: Perceptions of place by domestic visitors. Journal of Sustainable Tourism, 11(4), 307-321.

Sharpley, R., \& Telfer, D. J. (2002). Tourism and development: Concepts and issues. Clevedon: Channel View Publications.

Silver, I. (1993). Marketing authenticity in third world countries. Annals of Tourism Research, 20(4), 302-18.

Stafford Group. (2001). A study of barriers, impediments and opportunities for Māori in tourism: He matai tāpoi Māori. Retrieved March 13, 2007, from http://www.tourismresearch.govt.nz/Data-Analysis/Research-projects-reports-and-studies/ResearchReports / Maori-in-Tourism/

Statistics New Zealand. (2008). Tourism Satellite Account: 2007. Retrieved August 1, 2008, from 
http:/ / www.stats.govt.nz/NR/rdonlyres/899C59ED-5DE0-4241813E-

$\underline{\text { 6F0CC } 9784064 / 0 / 5907 T o u r i s m S a t e l l i t e A c c o u n t 2007 f f W E B . p d f ~}$

Taylor, J. P. (2001). Authenticity and sincerity in tourism. Annals of Tourism Research, 28(1), 7-26.

Tourism New Zealand. (2005). Annual Report 2004-2005. Retrieved December 10, 2008, from Tourism New Zealand. (2007). The New Zealand tourism strategy 2015. Wellington, NZ: Tourism New Zealand.

Tregear, E. (1891). The Maori-Polynesian comparative dictionary. Christchurch: Whitcombe and Tombs.

Walker, R. (1996). Nga pepa a Ranginui: The Walker papers. Auckland: Penguin Books.

Wlliams, H.W. (1975). A dictionary of the Maori language (7th ed.). Wellington, New Zealand: Government Printer.

Wilson, J., Horn, C., Sampson, K., Doherty, J., Becken, S., \& Hart, P. (2006). Demand for Maori eco-cultural tourism. Lincoln, Canterbury: Manaaki Whenua Press, Landcare Research.

Zygadlo, F. K., McIntosh, A., Matunga, H. P., Fairweather, J. R., \& Simmons, D. G. (2003). Maori tourism: Concepts, characteristics and definition, Tourism Recreation Research and Education Centre, Report No. 36, March 2003. 